\title{
Improved offer made to ex-GDR researchers
}

Berlin. The Humboldt University in Berlin has backed down from an attempt to give only 'second-class' contracts to 250 scientists funded under a programme to integrate east German scientists into universities in the new Länder following protests that the contracts were unfair.

In 1990, 2,000 top-rated scientists were transferred from the overstaffed research institutes of the former German Democratic Republic to the state-funded Wissenschäftler Integrations Programms (WIP), designed to help re-establish research in universities.

The DM600 million (US\$300 million) programme supported the scientists fully for two years up to last December, enabling them to find university posts. Further support is being provided during the first three years of their university employment, with the university paying an increasing proportion of their salary each year.

The original idea was that by 1996 all the WIP scientists would have permanent university posts. But the universities have resisted this, pointing out that since reunification they have fired thousands of their own staff, and have no desire to dismiss more in order to accommodate 'outsiders'.

It now looks as if only a handful of the scientists will have permanent positions when the state-subsidized period ends in 1996. In contrast, the number of short-term contracts issued to WIP scientists - 1,473 by universities and 207 by other institutes - has been much higher than expected.
But even here there have been problems. Almost all the universities in the new Länder offered the WIP scientists standard shortterm contracts. But the Humboldt University, the former East Germany's most important university, introduced special clauses in the contracts which appeared to give its 250 WIP scientists a 'second-class' status.

For example, nearly all were placed on the lowest point of the university pay scale, irrespective of previous experience. They have been required to accept a six-month probation period, even though many have been running lecture courses for more than a year. And the contracts state explicitly that the WIP scientists will not be given permanent employment at the end of three years.

Several groups of scientists have complained about these conditions. "They are humiliating and unfair, and certainly against the spirit of the WIP programme," says one WIP scientist.

Detlev Ganten, director of the Max Delbrück Centre for Molecular Medicine a national research centre in Berlin which took on a hundred WIP scientists in the programme's first two years - is among those who have declared their support. "I have a lot of sympathy for these people," he says. "Some have not been treated as they should have been."

But Ganten and others accept that Humboldt has itself been a victim of the times. Since reunification, the university has had to shed more than half of its staff,

\section{Gene transfer patent is revoked}

Munich. A patent granted in 1992 to the agrochemical and pharmaceutical company Clba-Geigy on a technique for transferring genes directly into plant cells has been revoked by the European Patent Office (EPO) following a successful challenge by the Swiss company Sandoz and the German AgrEvo, jointly owned by Hoechst and Schering.

Ciba-Geigy had claimed broad patent protection for its technique, which would have covered all methods for direct gene transfer without the ald of a vector, including chemical treatment or electroporation. Although direct gene transfer is not widely used by plant genetic engineers, the breadth of the patent had caused concern, because of fears that it could restrict the freedom of plant breeding companies in the future.

But Sandoz and AgrEvo last week persuaded the EPO to revoke the patent, based on work carried out at Ciba-Geigy's Friedrich Miescher Institute in Basel, on and all professors have had to be reselected through open competition.

The prospect of taking on a large proportion of WIP scientists seems to have been the last straw. Ganten claims that "with more administrative experience and less nervousness, it could all have run more smoothly". Wieland Hampel, of Berlin's research ministry agrees.

But the university itself claims that it placed restrictions on the contracts for financial reasons. Although the federal government provides an average of DM100,000 a year for each scientist, the university says the money is not sufficient to cover all the costs involved. Nevertheless, following the protests about its policy the university has agreed in principle to review all the positions offered to WIP scientists, and make up any shortfalls in pay considered necessary.

Alison Abbott

\section{India lifts curbs on foreign R\&D}

New Delhi. India has agreed to ease restrictions on foreign multinational companies wishing to set up research and development (R\&D) facilities in the country, in line with commitments under the revised General Agreement on Tariffs and Trade (GATT) concluded in Geneva last December.

With the exception of research in "atomic energy and related matters", foreign companies are now free to establish $R \& D$ centres in which they have a controlling stake in almost all areas of science and engineering.

In the past, the government has been cautious about allowing foreign investment in R\&D facilities. But given the present decline in public funding for research, combined with the reluctance of Indian companies to invest in their own research activities, the government has agreed to welcome foreign multinationals in the hope of stimulating the research base.

Foreign participation in applied science and technology will be allowed in a wide range of industries, including communications, electricity production, marine engineering, aeronautics engineering, construction and information technology.

The government will also allow multinationals to be majority equity holders in facilities for technical testing and analysis, in the hope that this will lead to an improvement in quality control systems and the general raising of technical standards.

Several multinational drug companies, including Astra of Sweden, have already established R\&D centres in India. Until now, however, the government has given permission for these centres only on a caseby-case basis.

K. S. Jayaraman 